\title{
Management of Student Entrepreneurship Development at the West Java-Indonesia Private Islamic College
}

\author{
Ahmad Rusdiana ${ }^{1}$, Rahman Setia ${ }^{2}$, Abdul Muin $^{3}$ \& Aam Abdillah ${ }^{4}$ \\ ${ }^{1}$ Islan State University, Sunan Gunung Djati, Bandung, Indonesia \\ ${ }^{2}$ Department of Islamic Economics Islamic College of Religion 11 April Sumedang West Java-Indonesia \\ ${ }^{3}$ Faculty and Teacher Training of the Sultan Maulana Hasanuddin State Islamic University, Banten-Indonesia \\ Correspondence: Ahmad Rusdiana, Islan State University, Sunan Gunung Djati, Bandung, Indonesia.
}

Received: June 24, 2020

doi:10.5430/ijhe.v9n6p286
Accepted: October 13, 2020

Online Published: October 14, 2020

URL: https://doi.org/10.5430/ijhe.v9n6p286

\begin{abstract}
This study aims to explore the relations between the factors of the start-up environment and entrepreneurial intentions of students in universities in Vietnam and the Philippines by combining key elements of the theory of reasoned action, theory of planned behavior, theory of entrepreneurial events and model of entrepreneurial potential. Research findings were expected to test the appropriateness of this proposed model in the context of Vietnam and the Philippines. A bilateral survey was carried out among 819 students at five universities in Vietnam and the Philippines and the Structural Equation Modelling was applied to calculate the causal factors of the students' entrepreneurial intentions. The findings suggested that subjective norms, entrepreneurial education, entrepreneurial desirability, and entrepreneurial motivation were positively related to perceived feasibility. Entrepreneurial education was the key determinant of entrepreneurial intention. Barriers for startups demonstrated a negative effect on the perceived feasibility. The central part of entrepreneurial education to entrepreneurial intention was confirmed in both states. Nonetheless, there are existing challenges in entrepreneurial education which required more respective supports from governments to promote the enterprise development.
\end{abstract}

Keywords: social value, civil society, innovation economic

Contribution/Originality: This study is a scrap of a subject field that extends the concept of "Development of Social Entrepreneurship, Management in Islamic Higher Education through the Social Competence Project" l. It is expected to provide benefits, particularly for several parties involved, and it is also expected to offer alternatives for the community to develop new entrepreneurial activities.

\section{Introduction}

Students are agents of change in increasing the capacity of the surrounding community. As a millennial generation, students must be observant about the transformation of types of work that do not look formal. For students, self-preparation is very necessary so that when graduating students are not confused looking for work and do not increase the number of unemployed in Indonesia. For this reason, a real solution is needed to provide, one of which is to increase the entrepreneurial spirit of each individual student to be able to see opportunities to create creative innovations from the local potential of the community. Social entrepreneurship, for example, is a good form of change because the concepts raised are building businesses for social, economic and environmental problems. As agents of change, students are obliged to change themselves and the community to be more independent in an effort to improve their welfare through existing programs in higher education. Increasing the spirit of entrepreneurship in every individual in the community is one of the things that can be done by students as agents of change in improving the welfare of society. Social entrepreneurship is a social-based entrepreneurship aimed at the interests of the community rather than merely personal gain. This social entrepreneurship can be done individually or organizationally (Tan, Williams and Tan 2005 in Hasanah 2018). According to Dees (2001 in Utomo, 2014) in his book entitled "The Meaning of Social Entrepreneurship," socio-entrepreneurship as a combination and great passion in social mission accompanied by discipline, innovation, and determination as is prevalent in the business world. 
In Islam, form of entrepreneurial activity is not something new. Both are like two sides of a coin that cannot be separated. The Prophet Muhammad, his wife and his companions also carried out entrepreneurial activities. Although in the form of its study, there were no explicit rules governing entrepreneurship in the Islamic economy. Rasulullah Saw said "You should trade because in that trade there are 90 fortune doors that can be opened. In the history of Islam it is said that entrepreneurial activities have been carried out since the time of the Prophet and his companions, so in fact these entrepreneurial activities have become a characteristic for Muslims who have done it long ago. In other words, the business ethics that exist in Islam have long been developed into high-value ethics in upholding the benefit of business. This Islamic trading activity is also a vehicle for the people (Nurfaqih, 2018).

Rasulullah and most of his friends are international scale social entrepreneurs with unquestioned integrity and competence. The achievements of zakat, infaq, shodaqoh and their waqf are fantastic. At that time, Islamic civilization was so grounded. Islam as the religion of Rahmata nlil Alamin is not only felt by Muslims but far beyond the Arabian Peninsula when principle of being fair and prosperity are the priority of every leader or caliph (Siti Najma, (2016). Islam teaches entrepreneurship, From Mu'adz bin Jabal radhiyallahu 'anhu, he said: Rasulullah said: “... Truly the best income is the income of the traders who when speaking is not lying, if given the mandate is not treasonous, if they promise not to deny it, if they buy it is not condemning, if they sell it is not excessive (in increase prices), if debt does not delay repayment and when collecting debt does not make it more difficult for people who are in trouble." From the argument about trade above it is known that Islam strongly advocates for its adherents to be self-employed and prioritize, akhlakul karimah, in carrying it out. Islam teaches that in business it is not merely to seek worldly profit but an entrepreneur must also equip himself with the provisions of faith and shar'i knowledge, especially those relating to fiqh muamalah and business in order to become good and true entrepreneurs and not fall prey to matters unclean things.

Islamic Higher Education is one of the organizations engaged in the social field of Islamic education. The involvement of tertiary institutions in social entrepreneurship education for students will produce entrepreneurs, collaboration with industrial companies, communities directly involved in the development of social entrepreneurship programs to new models and theories that are born from measurable, directed research results, and sustainable. As a form of entrepreneurship development among students, universities need to instill an entrepreneurial spirit to students who have their own social sensitivity, so that they can educate the public effectively, directly, and measurably related to programs to improve welfare through sociopreneur. Masturin (2015) states that the empowerment of human capital has the ability to deliver human beings to rational, conscious, and critical thoughts to get out of their problems and provide reciprocal impacts to help other social problems so that the role of educational institutions is in fact able to implement empowerment through sociopreneurship. The implementation of strategies to produce a generation that has a community-based entrepreneurial spirit is an achievement for the tertiary institution. In addition, sociopreneurship has become a trend in today's youth as an alternative to survive in the midst of difficulties in finding work (Suyatna and Nurhasanah 2017).

The Social Competence Project is one of the strategies implemented by a private Islamic tertiary institution in West Java. This strategy requires students to be closer to the community because before doing the project students must get to know the community that will be targeted. Output of the Social Competence Project program is the creation of students who are sensitive to social problems that affect the change in society in the economic field. It also can foster students' sensitivity to business opportunities for themselves and the community. In addition, Social Competence is a program of assistance in science, technology, and art in an effort to improve the performance of social organizations. Based on the description above, the problem which is quite intriguing for the writer to explore further is how the implementation of Social Competence in the tertiary institution is able to produce graduates of social entrepreneurship and the extent to which the success of these activities can improve the community's economy (Nazat, 2018). An important aspect that becomes the point in this paper is how tertiary institutions become new sociopreneurship printers in Indonesia.

This competition is intended for students who are still active as a form of preparing young entrepreneurs who are sensitive to changes in society in the fields of education, environment, and economy. As participants in the Social Competency Project, students must continue to look for opportunities and create various innovative activities to improve the economic and social level of marginalized communities and understand social problems with entrepreneurial capabilities possessed to improve the welfare of the community in the fields of education, environment, and economy. In creating innovation students must understand the business model of the Social Competence Project. According to Kusumasari et al (2015), there are three aspects of sociopreneurship business design types, namely; value prepositions, value creation, and value capture. The value proposition relates to the formation of the organization, the goals to be achieved by the business, the social issues to be answered, who is the Published by Sciedu Press 
customer, and what is offered to customers or users of business services or products, value creation including business activity to achieve business value, the way of working, the sustainability of a company with whom the company cooperates, and financing the activity of a business, capturing the value of the way business gets profits, the definition of success for a business, and measurement of the performance of sociopreneurs or in achieving performance.

This identifies that social entrepreneurship must be able to run financially, socially, and environmentally responsible. It is interesting to study, with the answer to the problem. So this study is a bit of a study that offers the concept of "Development of Social Entrepreneurship Management in Islamic Higher Education Through Social Competence Projects". It is expected to provide benefits, especially for several parties involved, and is also expected to provide alternatives for the community to develop new entrepreneurial activities.

This study aims to describe the "Management of Student Entrepreneurship Development in Private Islamic Religious Colleges of West Java-Indonesia". Along with technological developments and information. Along with the demands of students as agents of change, they are obliged to change themselves and the community to be more independent in their efforts improve its welfare through existing programs in higher education. One of them is with the Social Entrepreneurship program. The model of social entrepreneurship activities is now becoming a trend in tertiary institutions as the implementation of tri dharma based on community service. social entrepreneurship activities as a medium of learning and community service in the Higher Education in order to increase the capacity and student learning outcomes, need to be traced to the truth through scientific studies, in-depth and specific research.

\section{Materials and Methods}

\subsection{Relevant Theories}

\subsubsection{Social Capital Theory and Social Competence}

Social capital is defined as the relationships and assets allocated in the network (Bourdieu, 1986; Burt, 1997; Coleman, 1988), and social capital has a positive effect on company performance (Baker, 1990), product innovation (Tsai and Ghoshal, 1998), and the formation of industrial breadth in the network (Walker, Kogut and Shan, 1997). Trust in relationships is an indicator of relationship quality, and is found to be positively related significantly to sales and innovative performance. Batjargal (2000) in his research which aims to analyze individual social relations and company performance in Russia, the results of his research show that there are different effects from the different dimensions of individual social capital on company performance. Relational embeddedness and resource embeddedness have a positive effect on company performance. While structural embeddedness has no effect on company performance. The limitation of this research in the dimension of social capital which only looks at the aspect of relationship attachment, still needs to be developed in the form of social capital (trust, commitment, reputation). Furthermore, it is called social competence. (NuritaAndriani, 2012).

Social competence is the ability to communicate and interact effectively and efficiently with students, fellow educators, education personnel, parents/guardians, and residents of surrounding communities. Next to the second sub competency; (a) communicating and interacting effectively and efficiently and empathy with participants effectively and efficiently as well as empathy with students, fellow educators, education personnel, parents and surrounding communities, (b) contribute to the development of education, both in schools and in the community, contributing to the development of education at the local, regional, national and global levels, and (d) utilizing information and communication technology to communicate and develop themselves. (Anugrahana (2016).

Social competence is very closely related to the skills to establish relationships/interactions with others in order to develop. As a vehicle for the development of these competencies, the social environment becomes a place for prospective teachers to improve social competence as a provision in carrying out the teaching profession. Social education can be done both formally in schools/colleges and informally in the community. These activities can take the form of religious, social and academic activities. Optimization of social capital was born from the initiatives of social entrepreneurs Innovation, social entrepreneurship combining creative and innovative concepts. This concept is based on unique ideas that add value to ideas, goods, events, and methods that are considered as new things by the community. (Hulgard 2010 in Utomo, 2014).

\subsubsection{Sociopreneurship}

Sociopreneurship or social entrepreneurship is now a trend in higher education as the implementation of tri dharma based on community service. Various methods of education and training are educational methods offered in improving entrepreneurial skills to be implemented in the community. The origin of the word Sociopreneurship is social and entrepreneurship which means as a person/organization that understands social problems and uses the Published by Sciedu Press 
ability of entrepreneurship to make social change. Simply stated Socipreneurship or social entrepreneurship is the act of someone who understands social problems and uses the ability of entrepreneurship to do social change, both in the fields of welfare, education and health (Santoso 2007). According to Wiguna (2013), Social Entrepreneur is an idea that arises first from the economic system in the European region which is oriented on the process and behavior. The aim is to improve social aspects and implement an integrated strategy between social and economic aspects so that their performance can be known from the contributions made in an effort to improve social aspects.

The concept of social entrepreneurship is an extension of the basic concept of entrepreneurship which has historically been recognized as an economic lever, especially in solving social problems (Noruzi, et.al 2010; Patra and Nath 2014, in (Nazat, 2018)). Individual behavior in entrepreneurship is an attempt to take advantage of opportunities and create value. For sociopreneurship, the intended value is social value because social entrepreneurship strongly emphasizes how to create ideas or ideas that are innovative in order to solve social problems. The four main elements in social entrepreneurship are, among others, social values, civil society, innovation, and economic activity (Hulgard 2010, in Utomo, 2014). Social Value is a real social benefit for the community and the environment. Civil Society is a form of initiative and participation of civil society by optimizing existing social capital in the community. Innovation is an innovation that is carried out in solving problems by looking at the local wisdom of the community, while Economic Activity is a balance between social activities and business activities to ensure the independence and sustainability of the organization's social mission.

The concept of sociopreneur has been a long time ago and has been developed in universities one of the universities in the UK such as Skoll Center for Social Entrepreneurship at Oxford University. In the United States also established centers for the study of social entrepreneurship, for example the Center for the Advancement of Social entrepreneurship at Duke University. Examples of social entrepreneurship practices are found in foundations that have been globalized, specifically looking for social entrepreneurs in various parts of the world to foster and provide funds for the drivers of social change, the Ashoka Foundation (Nicholls 2006, in (Nazat, 2018).

Islam is a religion that combats poverty. In Islam poverty alleviation is not based on charity but is based on full employment. In this case, of course, social entrepreneurs take an important role. In addition to providing employment, as explained above, social entrepreneurship must be able to become an agent of change (change agent) to realize equality and equitable distribution of social welfare. Rasulullah and most of his friends are international social entrepreneurs with undoubted integrity and competence. The achievements of zakat infaq shodaqoh and their waqf are fantastic. At that moment Islamic civilization was so down to earth. Islam as a religion Rahmatan lil Alamin is not only felt by Muslims but far beyond the Arabian Peninsula when the principles of justice and prosperity are the priority of every leader or caliph (SitiNajma, 2016).

In Indonesia, the term sociopreneur is starting to become a trend of young people. Evidently some young social entrepreneurs have succeeded in contributing to the resolution of community socio-economic problems. Research (Suyatna and Nurhasanah 2017) shows that young people with a variety of very fast and sophisticated technologies have begun to look for social business opportunities as a survival option in the midst of their difficulty in finding jobs. The existence of increasingly sophisticated technology is also used by youth for profitable business capital while providing opportunities for the surrounding community to take advantage of the technology. Research (Palesangi and Muliadi 2012) also describes the success stories of young people who are concerned with social entrepreneurship, namely Goris.

Mustaqim is a founder of the Garut Asgar Muda foundation, a foundation that focuses on youth empowerment (Garut, West Java). ElangGumilang provides a simple and healthy home specifically for low-income people, and M. Junerosano is the founder of Greneration Indonesia, a social enterprise that focuses on promoting environmentally and friendly lifestyles. This shows that Sociopreneurs in Indonesia have become a solution to the social and economic problems of the young generation as agents of change. Reporting from the Ministry of Cooperatives and SMEs, BPS data shows an increase in the number of entrepreneurs. From the previous it is $1.6 \%$ to $3.1 \%$ of the population and this has broken the psychological limit set at $2 \%$. The number of entrepreneurs in a country is often considered an indicator of progress. Benchmark of at least $2 \%$ of the population must work as entrepreneurs. With a population of 250 million people, this country must have at least 5 million people in entrepreneurship (Kominfo, 2018 in Nazat, 2018). This means that there are still many opportunities to become entrepreneurs in the current digital era. The existence of entrepreneurship programs developed by universities is expected to provide entrepreneurship education for graduates to be able to fill these opportunities.

Social entrepreneurs (social entrepreneurs) or social entrepreneurs can be referred to as individual visionaries who are able to provide creative solutions to solve some of the social problems that occur around. They have the ability to 
identify problems, develop ways to change the system and disseminate ideas so that it can move the whole community to work together to overcome the various problems encountered. Three important aspects in the development of social entrepreneurship are human aspects, profit aspects, and environmental aspects. It is almost similar to Ashoka Fellows, founded by Bill Drayton in 1980, that mentions the characteristics of social entrepreneurial activities as follows: 1) not for profit making, 2) doing business for social purposes, and 3) a mixture of the two goals, ie not for seeking profit, and looking for profit, but for social purposes (Utomo, 2014).

\subsubsection{Policy Development of Socio-preneurship and Higher Education}

Every human being in principle has a role as a carrier of change as well as students who have strong principles as agents of change must be able to bring change in the surrounding environment. As already explained above that socio-preneurs are not new, this term already existed in the 80s which began in European countries. Entrepreneurship Education conducted by universities in formal education is expected to produce students who have an entrepreneurial spirit. In addition students are part of a dynamic community group. This means that students can follow changes in society, and with intellectual capacity students are able to develop themselves.

Higher education as one of the facilitators in producing graduates as a young generation who have the obligation to educate, teach, train and motivate their students so that they become intelligent generations who are independent, creative, innovative, and able to create various job opportunities (business). Therefore, universities need policies and programs in developing entrepreneurship from students so that universities can become university entrepreneurs. Even since 2000, the course "Entrepreneurship Management" has been implemented in higher education institutions based on Decree of the Minister of National Education number 232 dated 20 December 2000, regarding guidelines for the preparation of the Higher Education Curriculum and Student Learning Assessment, by determining the core curriculum of the Bachelor Program and Diploma Program, consisting from groups (1) Personality Development Subjects (MPK), (2) Scientific and Skills Subjects (MKK), (3) Work Skills Subjects (MKB), (4) Work Skills Subjects (MPB), (5) Social Life Subjects (MBB). While the course "Entrepreneurship Management" is grouped in the Group of Sciences and Skills (MKK) (Rudsiana, 2013).

In Universitas Islam Nusantara (UNINUS), Bandung for example, the development of social entrepreneurship programs is carried out with the Career and Entrepreneurship Center (PKK) program. This PKK program provides opportunities for scholars who have not been absorbed by the world of work to pursue social entrepreneurship. The PKK program is divided into three stages, namely cloning sociopreneurship, bachelor deployment to rural areas, and off-takers of entrepreneurial products. The initial stage, the PKK focused on cloning programs of various forms of rural-based entrepreneurship that have been successful. In its implementation, the PKK program involves business groups, philanthropy, central and regional governments, recent graduates, and the international community (Alamsyah 2018 in Nazat, 2018). In addition, the development of entrepreneurship is carried out by holding competitions under the title SOᄀPREMA. The British Council and the Arthur Guinness Fund since 2010 have organized competitions in the development of social entrepreneurship in the Community-Based Entrepreneurship Competition (CEC).

State Islamic University (UIN), Sunan Gunung Djati Bandung by establishing the Center for Business Development and Social Entrepreneurship (P2BKS), is one of the chancellor's policy steps as outlined in his work plan to encourage entrepreneurial growth among the academic community referring to PMK no. 82 years old. 2018 about financial management flexibility. Based on these references the UIN SGD UIN Business Development Center not only serves as a driving force to explore the potential of assets in order to provide benefits but also foster an entrepreneurial spirit, especially among students and their academic interests. (P2BKS work guidelines, 2019).

Next is the object of research, the Islamic Economic High School (STEI) Ar-RisalahCiamis, West Java, in developing entrepreneurship. It is carried out with a competition, namely the Social Project Competition. This competition is a direct implementation of the concept of social entrepreneurship because students are directly involved in the community to implement their innovation and creativity. (Sasmita, 2019).

The Ministry of Youth and Sports, in collaboration with the Islamic University 45 of Bekasi and PT Astra International, held a Youth Entrepreneurship Lecture in the 45th Islamic University Meeting Hall in Bekasi. The aim of the program is to socialize, develop entrepreneurial character and give participants the ability to develop business plans and it is as an attempt by the government to foster interest in entrepreneurship among young people. The Ministry of Youth and Sports will carry out the First Stage of Entrepreneurship Lecture Activities 22 times, and the entrepreneurship lecture at Unisma is the 12th. This activity consists of four stages with a selection method at each stage. Phase one was held in 22 universities in the Greater Jakarta area. Stage two to four will be held at the Kemenpora Building, Jakarta. In addition to cooperate with 22 universities, Kemenpora also collaborates with PT Published by Sciedu Press 
Astra International Tbk, UMKM Friends, Aspirations (Association of Writers and Inspirators throughout Indonesia), and opens opportunities for all stakeholders who are interested in partnering in creating entrepreneurial ecosystems and helping the growth of new entrepreneurs. The Youth Entrepreneurship Lecture held at the 45th Islamic University Hall began with a welcoming dance, which was then continued with prayer readings, and remarks from the Chancellor of Unisma. Then representatives from the Minister of Youth and Sports, Deputy Assistant to Youth Entrepreneurship, Drs. Imam Gunawan, MAP, gave his remarks, then followed by the signing of the MoU and the exchange of placards. UNISMA presented Piet Cyntia Mawar, a culinary entrepreneur, and M. IkhtiaryGilang (owner Breakday/WMP) as a speaker to share their experiences in entrepreneurship, and generate entrepreneurial mindset for students who want to try entrepreneurship. 12 of the best entrepreneurs will be selected as nominees to receive access to entrepreneurship and follow the next steps which will be held in September-October 2019. (Kemenpora, 2019).

\section{Research Model}

This research is qualitative research using a phenomenological approach (Creswell et al., 2007) focuses on the description of data in the form of sentences that have a deep meaning from the informant and the observed behavior (Moustakas, 1994). Phenomenology is a philosophical approach to the study of experience, and the founding principle of phenomenological inquiry is that experience should be examined in the way that it occurs and in its own terms (Smith et al., 2009). Retrieval of qualitative data is done by means of surveys, observations, field studies, literature studies and interviews. Surveys, observations, and fieldwork are conducted in areas that are the object of Social Project Competition participants' activities, namely Citanduy River, Bojong Gede Village.

In this study the authors used the interview method with the method of in-depth interviews or questions and direct observation of the research object. Interviews were conducted with student staff who became the competition committee, participants, and residents of the activity area. Data collection is a systematic and standardized procedure to obtain the required data (Miles, et. al., 2014), some methods can be applied include the direct observation method, the method of using questions, special methods.

Limited time and cost, then it is determined a college with the criteria that do not have an entrepreneurial institution and there is an entrepreneurial college wife, carry out social entrepreneurship activities and there is a desire from the academic community to help the community. The research sample was selected by purposive random sampling with sample criteria considered by the authors. The research sample was STEI Ar-Risalah Ciamis students with sample criteria, namely (1) the sample was STEI Ar-Risalah Ciamis students, (2) Social Project Commission participants, (3) anyone who wanted to be respondents. This criterion is an inclusion criterion in which the research subjects can represent in the research sample that has the requirements to be a sample (Hidayat 2007).

The research model of this research is inspired by the combination of the above theories, including: (1) Social capital is defined as relationships and assets allocated in the network (Bourdieu, 1986; Burt, 1997; Coleman, 1988), and social capital has a positive effect on company performance (Baker, 1990), product innovation (Tsai and Ghoshal, 1998), and the formation of industry breadth in the network (Walker, Kogut and Shan, 1997). (in Andriani, 2012); (2) Social competence is the ability to communicate and interact effectively and efficiently with students, fellow educators, education personnel, parents/guardians, and residents of surrounding communities. (Grace, 2016); (3) Socio-preneurship or social entrepreneurship is the act of someone who understands social problems and uses the ability of entrepreneurship to make social change, both in the fields of welfare, education and health (Santoso 2007). (4) "Entrepreneurship Management" is grouped in the Group of Scientific and Skills courses (MKK) (Rudsiana, 2013). On that basis, the research model framework proposed in Figure 1. The following: 


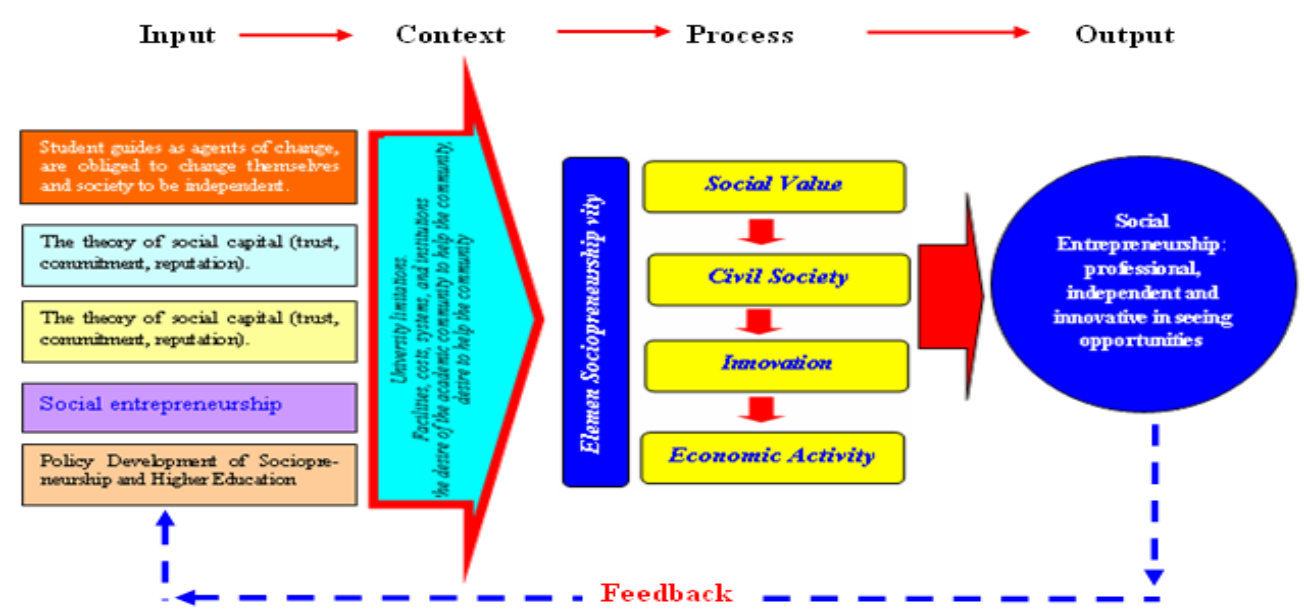

Source: developed by the author

This Study Model is a small study that offers the concept of "Management of Student Entrepreneurship Development in West Java-Indonesia Private Islamic Higher Education Institutions" Expected to provide benefits, aimed at some of the parties involved, and also expected to provide assistance to the community to develop entrepreneurial activities new.

\section{Discussion}

Various programs of activities are carried out by universities to produce young entrepreneurs as a solution to the development problem, namely unemployment. At the Ar-Risalah Islamic College of Economics (STEI), some treatments were taken to bring up OCB, Eco Week, Business Incubation, and entrepreneurship education through Sharia entrepreneurship courses. In addition, social-based entrepreneurs also become the discourse of higher education as a form of college dharma in community service. At STEI Ar-Risalah, the Sociopreneurship development program is carried out with a competition called the Social Project Competition.

This program is the first step in networking students who have an interest in entrepreneurship while at the same time bringing change to the community in improving their capacity to live. The activities proposed in the Social Project Commission can be in the form of business skills, environmental structuring and improvement, community institutional strengthening, introduction and understanding of customary law aspects, efforts to cure illiteracy and others for the community, both formal and informal. This is considered less productive. The results of an interview with the leadership of the PKM Corner Ar-Risalah Islamic College of Economics (STEI), Mr. Sasmita, stated that “.... entrepreneurship development was sought from the start of college through various programs namely Carachter Building Orientation in which there were business activities, business incubation, sharia entrepreneurship included in the course and Social Project Competition for social entrepreneurs. For this competition, it has been running for two years, the process that students must submit proposals that require commitment in the form of written cooperation from the community component to be assisted/ become the target audience" (Sasmita, 2019).

The aim of the activity is to develop students' interest in devoting their knowledge to the community through innovative, creative, and sustainable works in improving people's lives, both welfare, education and health. In addition, this activity is expected to be able to produce successful sociopreneurs and can make changes to the target society. The activity began in March-July with several stages carried out in the Social Project Competition, namely selection of proposals, presentations and implementation and then monitoring and evaluation. The competition was joined by active students at the Ar-RisalahCiamis West Java College of Islamic Economics (STEI). From the selection results, 10 proposals were selected to enter the presentation stage, after which five groups passed and could enter the implementation stage. In this implementation the implementation of each group will be seen by monitoring and evaluating. In 2018 there were three final candidates included in the monitoring and evaluation: Community Empowerment and Economic Development of Diaper Waste Management in the Citanduy Riverbanks with the heads of MiftahToha Al Haris, Our Dreams with the chairman Muhammad Teguh Devotion, Goat Milk Eta Wa with the chairman of LatifahRizkiNurohmah.

\subsection{Community Empowerment and Economic Development of Diaper Waste Processing in the Citanduy Riverbanks}

The social project for community empowerment and economic development of diaper waste processing on the banks of the Citanduy River was one of the participants, including three candidates who became the winners of this 
competition. Based on the group's sensitivity to social problems, namely garbage, the group tries to find solutions by utilizing the waste. With the target area of the Citanduy River, this student tried to give an understanding to the residents to utilize household waste rather than throw it away at the Citanduy River. More and more rubbish on the riverbanks, river pads, and TPS (Temporary Disposal Sites) will cause buildup because there is no waste processing that can reduce the buildup of waste. Trash in the river padding also cannot be decomposed, which causes pollution of the ecosystem and will cause inhibition of river currents which will trigger floods.

As a result of the accumulation of rubbish, the community and the government get ugly effects such as, foul odors, dirty, and cause the emergence of various diarrheal diseases, DHF (dengue fever) and so on. In this Social Project, new thoughts and breakthroughs in treating waste are focused on disposable diaper rubbish from infants. The aim of this project is to make the diaper waste in the community an economic value item. Diapers are one type of waste that is difficult to decipher ecosystems. Students try to make this diaper rubbish for something that is useful for the citizens in the Kali Citanduy area and the processed products will have more selling value than reducing the existing diaper rubbish population. Through the self-water system developed as a basic material for diapers, this is used in plants that will be useful for plants to meet the nutrients needed. The implementation of this innovation will be applied at the seedling stage and the concept of urban farming. In addition, social projects can be made through the action of Citanduy River by people who jointly utilize diaper waste, and a socialization of village greening with village media sharing around Citanduy River. Seeing the condition of greening awareness that is declining, greening can be a solution to improve awareness and use waste diapers around the Citanduy River. The benefits in the dissemination of knowledge about innovation in the development of self-watering system will later be useful for the implementation of the Citanduy River community's daily cultivation.

Utilization of diaper waste is as a planting medium for ornamental plants and vegetables. The community provides space for students to provide teaching on waste management and a place to realize the program, starting from the preparation stage, namely observation and socialization, the design of all available materials as well as trials and finally the implementation of hands-on practical training. Students also make a village garden using planting media for ornamental flowers from diaper waste placed in a used colored bottle container. Making vegetables for daily needs is also done. This is expected to reduce spending on vegetables. The business process is carried out by making waste banks, especially diapers. In the future, every diaper collected will be exchanged with the needs of the house; such as bath soap, de $\neg$ general, and others, so that this activity can become a social entrepreneurship for students and the community around the Citanduy River. This is in accordance with the elements of social entrepreneurship. What is conceived by Hulgard is that Social Value in this context has made a real impact on social benefits for the community and the surrounding environment, Kali Citanduy.

Our dream is a social project for students related to development issues, namely an increase in the literacy index among the people. Quality of Human Resources (HR) is one that affects the development of a nation. Good human resources cannot be separated from the educational process, both formal and informal. It was from the strong desire of a group of students to educate the nation that the learning group "Our Dreams" was established in BojongGede Village, Kec. CijeunjungCiamis. In addition to improving the cognitive abilities of the community, this group tries to improve the economy to create a financially independent village community so as to be able to finance the education of the young generation there.

Potential mapping has been carried out in the pre-poposal stage and it is found that the village has a very low level of education for children graduating from high school (SMA), many children who drop out of school or only go to junior high school. The population of BojongGede Village is 65 people. 20 of them are children and 10 children are in junior high school education. While there is no further education at the higher school level because there is no government assistance in the form of School Operational Assistance (BOS). Judging from its economic potential, BojongGede Village has a lot of melinjo trees, coconut trees, and yards that have not been used optimally.

The activities carried out combine verbal, religious, and business aspects. The verbal aspect is reflected in the learning activities of English and basic Arabic. The religious aspect is reflected in the activities of improving the reading of the Koran, and the business aspect is reflected in the business learning activities through information technology. Three times a week non-formal school learning activities carried out. During the activities the empowerment process was carried out, such as training for potential beneficiaries, for example sausages made from melinjo skin in collaboration with participants in the business plan competition, making cages for stalled cattle in collaboration with young village youths whose aim was to increase the community economy in Bojong Gede Village. So that in the future the activity is able to finance the education of children there and participate in the development program, which is literacy. The results of monitoring of social entrepreneurship have not yet reaped maximum results 
because the new ducks risen. This is in accordance with the elements of social entrepreneurship. What is conceived by Hulgard is that Civil Society is a form of initiative and participation of civil society by optimizing existing social capital in the community, in this context, residents in BojongGede Village, which have felt inspired and helped by this activity, eventually being able to finance education as a generation young hope of the nation.

\subsection{SUKAWA (Etawa Goat Milk)}

The development of the Sociopreneur was carried out in Sidamulya, a village that has the potential for etawa goat milk which is sufficient because the villagers have a communal enclosure for the cultivation of the goat. So far, the results of etawa goat milk have not been optimal in improving the standard of living of residents because their products are still in the form of liquid milk and there has been no innovation from these products. Seeing this, students took the initiative to help solve the problem by helping marketing, teaching sales accounting records, and teaching processing of health product innovations by utilizing etawa goat milk to be used as soap as a citizen effort, so that goat farmers in Sidamulya can be active with maximum returns.

The existence of this etawa goat milk processing into bath soap and beauty masks is expected to increase income for residents of the goat farm and the surrounding community. In addition to opening business opportunities for local residents, etawa goat milk processing into soap and beauty masks can also maximize the use of goat milk into economically valuable products. Several stages were carried out from the location survey taking care of licensing to the hamlet or local village related to the introduction and direction of the use of etawa goat milk as a new commodity that is quite profitable and the raw material for making products. The team also coordinated with local cadets to help market the products that were produced later. The next step is to provide direction on how to make a face mask made from etawa goat milk. The program targets are farmers and PKK ladies and youth clubs in Sidamulya, to process etawa goat milk into soap products and face masks.

The monitoring and evaluation process is carried out after several months. The program runs so that the impact will be seen. From the results of monitoring and evaluation, the PKK Sidamulya village women began to innovate dairy products and market them even though it was still limited to the village's internal affairs. This program is expected to be able to bring an impact on changes in the economic level of the community through its potential. This is expected from the concept offered by Hulgard that Economic Activity has given a balance effect between social activities and business activities to ensure the independence and sustainability of the organization's social mission.

An interesting thing to observe from the three Social Project participants above is the similarity, namely the status of students, entrepreneurial spirit, creative and innovative, as well as having high social awareness. Youth like those who can combine social and business activities are needed by this nation. The journey of the three young teams is certainly still a long way to prove themselves as true social entrepreneurs, but our initiates need special appreciation because they not only develop business but also provide solutions to the socio-economic problems of society. Some of the roles that have been carried out are providing innovations related to the potential of the community that are the object of activities, providing production training to marketing, especially for those who love it. For more details it can be seen in the following table: 
Table 1. Sociopreneur Elements and Social Project Competition participants

\begin{tabular}{|c|c|c|c|}
\hline \multirow[b]{2}{*}{$\begin{array}{l}\text { Elements } \\
\text { Sociopreneurship }\end{array}$} & \multicolumn{3}{|l|}{ Social Project Participants } \\
\hline & $\begin{array}{l}\text { Participant } 1 \\
\text { (Processing of Diaper Tin } \\
\text { Citanduy) }\end{array}$ & $\begin{array}{l}\text { Participant } 2 \\
\text { s(Our Dreams) }\end{array}$ & $\begin{array}{l}\text { Participant } 3 \\
\text { (SUKAWA: Dairy } \\
\text { Innovation Etawa Goat) }\end{array}$ \\
\hline Social Value & $\begin{array}{l}\text { Society is becoming more } \\
\text { environmental care }\end{array}$ & $\begin{array}{l}\text { More society care } \\
\text { children's education }\end{array}$ & $\begin{array}{l}\text { about Youth goat breeder and PKK } \\
\text { mothers have container of creating } \\
\text { business community based }\end{array}$ \\
\hline Civil Society & General Society & $\begin{array}{l}\text { Children of age sc } \\
\text { villagers Bojong } \\
\text { Village }\end{array}$ & $\begin{array}{l}\text { chool,Processing various product variants } \\
\text { Gedemade from goat milk }\end{array}$ \\
\hline Innovation & $\begin{array}{l}\text { Integrating products and } \\
\text { program for campaigning } \\
\text { environmental pelestraian }\end{array}$ & $\begin{array}{l}\text { Integrating learning } \\
\text { cognitive and business }\end{array}$ & $\begin{array}{l}\text { Processing various variants products } \\
\text { made from goat milk }\end{array}$ \\
\hline Economic Activity & $\begin{array}{l}\text { Diaper trash bank, plant } \\
\text { crops household }\end{array}$ & $\begin{array}{l}\text { gMake a cage commun } \\
\text { entok }\end{array}$ & $\begin{array}{l}\text { al forEstablishment of a dairy house } \\
\text { (innovation of various processed } \\
\text { milk) }\end{array}$ \\
\hline
\end{tabular}

Source: processed by researchers

The table above shows that the development of entrepreneurial management carried out has fulfilled the concept of social entrepreneurship. Social Value, the three participants in implementing innovation and creativity provide direct and indirect social benefits to the community of the object of activity both in BojongGede Village, Sidamulya Village in Citanduy River. Participants provide the skills and abilities of citizens to take advantage of business opportunities from the existing potential. The three participants of the Social Project Competition have a goal to help the community find business opportunities by providing skills to create a community-based business platform. Our dream, for example, is for participants to make an entog as a pilot project in developing the efforts of residents of BojongGede Village to be able to pay for children's education. Civil Society, the involvement of the object of activity (social capital) in the development of social entrepreneurship will make the success of the competition participants. Participants in the empowerment of diaper waste treatment make the community a potential that needs to be developed. While for Our Dreams it is more in school-age children. SUKAWA prioritizes the development of potential empowerment for PKK mothers.

The optimization of social capital was born from the initiatives of social entrepreneurs (Hulgard 2010 in Utomo, 2014). Innovation, social entrepreneurship combines creative and innovative concepts. This concept is based on unique ideas that add value to ideas, goods, events, and methods that are considered new by the community (Hulgard 2010 in Utomo, 2014). Innovations made by the three Social Project Competition participants vary, community empowerment on the banks of the Citanduy River innovates through diaper waste, waste diapers are processed into planting media which at the same time help to campaign for environmental sustainability, while for our dreams, invest in establishing educational programs with various learning methods, as well as mapping the potential and results of mapping discussed with residents of BojongGede Village are to be developed. Innovating by making soap from goat's milk the final element is Economic Activity, in accordance with the goal of developing social entrepreneurship, which is to solve problems with business. The Social Project Competition activity must also be able to have an impact on improving the people's economy. In this case the harmony between social activities is needed. To maintain harmony between social and economic activities so as to ensure independence and sustainability, the social mission that must be developed is to maintain rights and obligations and establish a sense of kinship (Prayogo, 2017). The economic activity of community empowerment on the banks of the Citanduy River in the future is the existence of a diaper waste bank for processing plants and then providing an exchange for diaper collectors. In addition, the planting media will be planted with plants for family needs such as mustard greens, eggplants, etc. resulting in savings for consumption expenditure. While Our Dream, it is an economic activity developed through an entog farm, sospro participants that provide entog seeds and entog enclosures to be managed by the community so that the results can be used for business residents of BojongGede Village. For SUKAWA, it is 
economic activities carried out through reactivation of a long dormant dairy house to be used as a processing facility as well as various business products from goat milk for PKK mothers in Permanent Occupancy 3 Sidamulya area.

\section{Conclusion}

Social Project activities become very important in building student independence in the midst of the crush of finding work. Higher education must be able to create graduates who are ready to face work competition and be able to create job opportunities by providing knowledge and entrepreneurial skills that have a high level of social sensitivity so as to change the surrounding environment. The results of the study indicate that the impact felt by the three objects of activity namely Citanduy River, Bojong Gede Village, Sidamulya is in accordance with elements of social entrepreneurship.

The most visible result of this competition is the increase in community knowledge related to skills as capital to gain added value so as to increase people's income. Based on the picture of the competition participants who passed the implementation phase, it can be concluded that this competition can produce Socio-preneur who can change society to live better in terms of education, health, and the economy. This means that this activity can provide benefits for the students concerned, the community and also for universities such as providing a balance of academic ability, attitude ability, and ability to work in order to develop themselves, the community either as a professional, independent, and innovative social entrepreneur in seeing opportunities which exists. So that they can exploit potentials such as making a reading house made by the two participants and a dairy house to make a variety of products from goat milk such as bathing soap as well as innovating to make a planting medium from diapers to create a garden in the Citanduy River

\section{Research Model}

This research is qualitative research using a phenomenological approach (Creswell et al., 2007) focuses on the description of data in the form of sentences that have a deep meaning from the informant and the observed behavior (Moustakas, 1994). Phenomenology is a philoshopical approach to the study of experience, and the founding principle of phenomenological inquiry is that experience should be examined in the way that it occurs and in its own terms (Smith et al., 2009). Retrieval of qualitative data is done by means of surveys, observations, field studies, literature studies and interviews. Surveys, observations, and fieldwork are conducted in areas that are the object of Social Project Competition participants' activities, namely Citanduy River, Bojong Gede Village.

In this study the authors used the interview method with the method of in-depth interviews or questions and direct observation of the research object. Interviews were conducted with student staff who became the competition committee, participants, and residents of the activity area. Data collection is a systematic and standardized procedure to obtain the required data (Miles, et. al., 2014), some methods can be applied include the direct observation method, the method of using questions, special methods.

\section{References}

Andri Anugrahana. (2016). Enhancing Basic Competencies of Students Prospective Primary Teachers in Mathematics Education Subjects With Innovative Learning Models. Research Journal (Special Edition of PGSD), 20(2), (December 2016), 182-187. Available in: e-journal.usd.ac.id >index.php〉 article >download.

Creswell, J. W., Hanson, W. E., Clark Plano, V. L., \& Morales, A. (2007). Qualitative research designs: Selection and implementation. The counseling psychologist, 35(2), 236-264. https://doi.org/10.1177/0011000006287390

HardiUtomo. (2014). Fostering Interest in Social Entrepreneurship. Journal of Among Makarti, 7(14), 1-16.

Hidayat. (2007). Nursing Research Methods and Data Analysis Techniques. Surabaya: Salembamedika.

Kasiram. (2008). Quantitative-Qualitative Research Methodology. Malang: UIN Malang Press.

Kusumasari, Suyatna \& et al. (2015). Understanding the Social Entrepreneurship Business Model in Indonesia. Yogyakarta: GavaMedia.

Lak Nazhat El Hasanah. (2018). Development of Social Entrepreneurship in Higher Education Through Social Project Competition. Journal of Youth Studies, 7(2), 90-99.

Masturin. (2015). Community Empowerment Model with Social Entrepreneurship Approach: Analysis of Social Entrepreneurship Characteristics. INFERENCE, Journal of Social Research Religion, 9(1), 159-82.

Miles, B. M, Huberman, A. M., \& Saldana, J. (2014). Qualitative data analysis methods sourcebook. Los Angeles: Sage publications. 
Ministry of Youth \& Sports. (2019). Kemenpora Young Entrepreneurship Lecture Program Arrives in Bekasi. [Online] available: https://img.beritasatu.com/cache/beritasatu/910x580-2/1562670252.jpeg

Moustakas, C. (1994). Phenomenological research methods. London: Sage publications. https://doi.org/10.4135/9781412995658

Muhammad IsnanNurfaqih, RizqiAnfanniFahmi. (2018). Social Entrepreneurship (Social Entrepreneurship) in the Islamic Economic Perspective. Islamic Public Finance Working Paper. UII 8(1), 1-15.

Nazir. (2014). Research Methods. Bogor: Ghalia Indonesia.

Nurita Andriani. (2012). Model Hubungan Modal Sosial, Kompetensi Pemasaran (Marketing Intelligence dan Marketing Innovation) dalamMempengaruhiKinerjaPemasaran.JurnalAplikasiManajemen, 10:1 (Janiari 2012), 50-59. Tersediadalamhttps://jurnaljam.ub.ac.id/index.php/jam/article/view/399/436

P2BKS Team. (2019). Guide to developing Social Entrepreneurship. Bandung: Business Development Center of UIN SGD Bandung.

Palesangi \& Muliadi. (2012). Indonesian Youth and Social Entrepreneurship. Indonesian Youth and Social Entrepreneurship, 1(94).

Prayogo, Caroline. (2017). Descriptive Study of Social Entrepreneurs on Agfa Owners in Sidoarjo, East Java, Indonesia. AGORA, 5(1), 1-6.

Rusdiana, A. (2014). Entrepreneurship: Theory and Practice. Bandung: Loyal Reader.

Santoso, Setyanto. (2017). The Role of Social Entrepreneurs in Development. Malang: UIN Maliki.

Sasmita. (2019). Interview about entrepreneurship development is sought from the beginning of college entry through various programs namely Carachter Building Orientation.

SitiNajma. (2016). Social Entrepreneurship in Islamic Economic Perspective. Journal of Muslim Intellectual Enlightenment Sarwah, 15(I), 57-70.

Smith, J. A, Flowers, P., \& Larkin, M. (2009). Interpretative phenomenological analysis. London: Sage publications.

Sugiyono. (2016). Quantitative, Qualitative, and R\&D Research Methodologies. Bandung: CV. Alfabeta.

Suyatna, Hempri \& YantiNurhasanah. (2017). Sociopreneurship as a Career Trend in Youth. Journal of Youth Studies, 6(1), 527-37. https://doi.org/10.22146/studipemudaugm.38011

Syafrudin, Ahmad DasukiAly, S., \& TejaSubakti. (2018). Marketing of Outlet Distributor Products in the Review of Islamic Business Ethics. Al-Mustashfa: Journal of Islamic Economic Law Research, 3(2), 223-235.

Wiguna, AtuBagus. (2013). Social Entrepreneurship and Socio-Entrepreneurship: An Overview with an Economic and Social Perspective. FEB Student Scientific Journal, 1(1), The library is written in red as an additional reference from the Research model.

\section{Copyrights}

Copyright for this article is retained by the author(s), with first publication rights granted to the journal.

This is an open-access article distributed under the terms and conditions of the Creative Commons Attribution license (http://creativecommons.org/licenses/by/4.0/). 